\title{
Seasonality of nematode larvae in Iguanodectes spilurus (Characidae) an ornamental fish from northeastern Para, Brazil
}

\author{
Rodrigo Yudi FUJIMOTO ${ }^{1 *}$, Ellem Cristina Silva dos ANJOS$^{2}$, Fabrício Menezes RAMOS², \\ Maurício Laterça MARTINS ${ }^{3}$
}

\section{ABSTRACT}

The current study presents a parasitological survey of larval nematodes from freshwater ornamental fish Iguanodectes spilurus caught in the watercourse of the Caete River, in the northeast region of the State of Para, Brazil. A total of 176 specimens, $1.36 \pm 0.75 \mathrm{~g}$ weight and $5.53 \pm 0.98 \mathrm{~cm}$ total length, were analyzed. Nematode larvae were identified as Capillaria sp., Procamallanus sp. and Anisakidae, with prevalence of $70.45 \%$ and infection intensity ranging from 1.81 to 4.70 larvae. The highest prevalence $57.38 \%$ occurred in the liver, but no seasonality was observed, indicating high infection throughout the year. Seasonality was observed in fish parasitized in the stomach, intestine and caecum, with prevalence and mean intensity of $17.61 \%$ and 2.32 parasites, $12.5 \%$ and 1.81 parasites, $10.79 \%$ and 2.21 parasites, respectively. The highest degree of infection was observed in the rainy season, probably due to increased availability of intermediate hosts or food.

KEYWORDS: Characidae, Parasitology, Seasonality, River.

\section{Sazonalidade de larvas de nematóide em Iguanodectes spilurus (Characidae) um peixe ornamental no nordeste do Pará, Brasil}

\section{RESUMO}

O presente estudo apresenta um levantamento parasitológico de larvas de nematóides de Iguanodectes spilurus capturados no fluxo do Rio Caeté, nordeste do Pará, Brasil. Um total de 176 espécimes com médias de 1,36 $\pm 0,75 \mathrm{~g}$ de peso e 5,53 $\pm 0,98$ $\mathrm{cm}$ de comprimento total foram analisados. Foram identificados em 124 peixes os nematóides Capillaria sp., Procamallanus sp. e da família Anisakidae, apresentaram uma prevalência de 70,45\% e intensidade de infecção de 1,81 a 4,70 larvas. A maior prevalência foi de $57,38 \%$ no fígado, mas não foi observada sazonalidade, indicando alta potência de infecção ao longo do ano. A sazonalidade foi observada em peixes parasitados no intestino, estômago e ceco com prevalência e intensidade média de $17,61 \%$ e 2,32 parasitas, $12,5 \%$ e 1,81 parasitas, $10,79 \%$ e 2,21 parasitas, respectivamente. A maior infecção foi encontrada na estação chuvosa, provavelmente devido ao aumento da disponibilidade de hospedeiros intermediários ou de alimentos.

PALAVRAS-CHAVE: Characidae, Parasitologia, Sazonalidade, Rio.

\footnotetext{
Embrapa Tabuleiros Costeiros'. Av Beira Mar 3250 Caixa Postal 44 - CEP 49025-040 - Aracaju, SE - Brasil. Phone: 55-79-40091300, Fax: 55-79-40091369, * e-mail: ryfujim@hotmail.com

2 Ichthyoparasitology and Aquaculture Laboratory - Federal University of Para. Al. Leandro Ribeiro s/n, CEP 68600-000, Bragança - PA - Brasil. Phone: 55-91-82905437, e-mail: fabriciomramos@gmail.com

${ }^{3}$ Health Laboratory of Aquatic Organisms, Aquaculture Department, Federal University of Santa Catarina. Rod. Admar Gonzaga 1346, CEP 88040-900, Florianópolis - SC - Brasil. Phone: 55-48-37219923, e-mail: mlaterca@cca.ufsc.br
} 


\section{INTRODUCTION}

The freshwater fish Iguanodectes spilurus (Günther, 1864) (Characidae), commonly found in Brazil and known as "piaba comprida", is of great ecological importance in aquatic ecosystems serving as a foraging fish species in the food chain and as ornamental fish (Vari 1977).

However, no records have been found on its biology and parasitic fauna. Climatic and aquatic alterations may interfere in the balance host/parasite/environment (Moraes and Martins 2004). The parasitic fauna of native freshwater fish is strongly related to nematodes, which, in turn, may be found as encysted larvae in the internal organs (Eiras et al. 2006). The effects of nematode larvae infection on fish might be related to the life cycle, degree of infection, site of infection, nutritional condition and immune response (Eiras et al. 1998).

The presence of nematode larvae in the visceral cavity and their migration to other organs such as the liver, muscle and mesentery originate cysts, which in some cases can provoke morphological alterations in the organs (Rodrigues et al. 2002).

This study evaluated the parasitic infection by nematode larvae in I. spilurus from northeastern Pará state, Brazil, and their relation with the dry and rainy seasons and condition factor.

\section{MATERIALS AND METHODS}

A total of 176 specimens of I. spilurus were caught monthly for parasitological assessment with the use of net and sieve in the Chumucui stream (01012'38.3”S, 046 $\left.{ }^{\circ} 47^{\prime} 31.7^{\prime \prime} \mathrm{W}\right)$, a tributary to the Caete River, municipality of Bragança, northeastern Pará state, Brazil, from June 2006 to June 2007.

The water quality was measured at $30 \mathrm{~cm}$ depth as follows: $\mathrm{pH}$, by portable $\mathrm{pHmeter}$ (Quimis Q-400 BC/BD; Quimis, Sao Paulo, Brazil), dissolved oxygen and temperature, by oxymeter (Lutron DO-5510; Lutron, Taipei, Taiwan). Accumulated rainfall in each month was obtained from the data provided by the National Institute of Meteorology INMET to determine the dry and rainy periods according to Schaeffer-Novelli and Cintrón (1986).

The fish were transferred alive to the Ichthyoparasitology and Aquaculture Laboratory at the Federal University of Para. They were euthanized in benzocaine solution $\left(0.1 \mathrm{~g} \mathrm{~L}^{-1}\right)$ and then measured and weighed for posterior parasitological analysis (Eiras et al. 2006). Nematode identification was performed according to Travassos et al. (1928), Thatcher (2006) and Eiras et al. (2006), and prevalence and mean intensity of infection were calculated according to Bush et al. (1997).

Based on the length and weight data, the allometric condition factor was calculated according to the formula:
$K a=W / L^{b}$, where $W=$ weight $(\mathrm{g}) ; L=$ total length $(\mathrm{cm})$ and $b=$ angular coefficient of relation weight/length, estimated by the equation $y=a x+b$, as recommended by Le Cren (1951).

Values of weight and total and standard length were submitted to the $T$ test in relation to the dry and rainy seasons. The data from prevalence and mean intensity in each organ were correlated to weight, total and standard length and condition factor, as well as to $\mathrm{pH}$, dissolved oxygen and temperature, by the Pearson's correlation matrix. Statistical tests were performed in the Biostat 4.0 software.

\section{RESULTS}

No significant difference between the mean values of weight, total length and standard length with the condition factor was found (Table 1). The dry period (rainfall $<100 \mathrm{~mm}^{3}$ ) corresponded to August 2006 - January 2007, while the rainy period (rainfall $>100 \mathrm{~mm}^{3}$ ) corresponded to June - July 2006 and February - June 2007.

Measures of dissolved oxygen in water $\left(5.36 \pm 1.00 \mathrm{mg} \mathrm{L}^{-1}\right.$, ranged from 3.9 to $6.8 \mathrm{mg} \mathrm{L}^{-1}$ ) were not considered inadequate to the survival of I. spilurus. During the dry season (August through December 2006, and January 2007), increased $\mathrm{pH}$ was observed $(\mathrm{pH}=7.81 \pm 0.55)$ compared to the rainy season $(\mathrm{pH}=6.96 \pm 0.32)$.

No correlation between $\mathrm{pH}$, oxygen and temperature with parasitological indexes (prevalence and mean intensity of infection) was observed (Tables 2 and 3). Significant increase $(\mathrm{P}<0.01)$ in the weight and length of fish was observed in the rainy period (Figure 1).

Nematode larvae were identified as Procamallanus sp. (Camallanidae) $\mathrm{L}_{3}$, Capillaria sp. (Capillariidae), and anisakid

Table 1. Monthly mean values and standard deviation of weight, total length $(\mathrm{TL})$, standard length (SL) and condition factor of Iguanodectes spirulus from northeastern Pará state, Brazil.

\begin{tabular}{lcccc}
\hline Months & Weight $(\mathrm{g})$ & TL $(\mathrm{cm})$ & $\mathrm{SL}(\mathrm{cm})$ & Condition factor \\
\hline Jun/06 & $1.96 \pm 0.91$ & $6.04 \pm 0.86$ & $5.29 \pm 0.80$ & $6.91 \times 10^{-4} \pm 1.58 \times 10^{-4}$ \\
\hline Jul/06 & $0.95 \pm 0.30$ & $5.46 \pm 0.70$ & $4.95 \pm 0.71$ & $5.75 \times 10^{-4} \pm 2.28 \times 10^{-4}$ \\
Aug/06 & $0.92 \pm 0.44$ & $5.04 \pm 0.69$ & $4.49 \pm 0.71$ & $7.49 \times 10^{-4} \pm 2.49 \times 10^{-4}$ \\
Sep/06 & $0.83 \pm 0.27$ & $4.59 \pm 0.49$ & $4.14 \pm 0.41$ & $1.03 \times 10^{-4} \pm 2.50 \times 10^{-4}$ \\
\hline Oct/06 & $1.00 \pm 0,35$ & $4.88 \pm 0.58$ & $4.36 \pm 0.54$ & $9.25 \times 10^{-4} \pm 1.81 \times 10^{-4}$ \\
Nov/06 & $1.05 \pm 0,42$ & $5.27 \pm 0.89$ & $4.76 \pm 0.87$ & $7.42 \times 10^{-4} \pm 3.07 \times 10^{-4}$ \\
Dec/06 & $1.15 \pm 0.00$ & $5.00 \pm 0.00$ & $4.50 \pm 0.00$ & $9.67 \times 10^{-4} \pm 0.00$ \\
Jan/07 & $1.80 \pm 1.24$ & $6.1 \pm 1.50$ & $5.40 \pm 1.35$ & $6.49 \times 10^{-4} \pm 3.64 \times 10^{-4}$ \\
Feb/07 & $2.34 \pm 0.71$ & $6.62 \pm 0.67$ & $5.53 \pm 1.53$ & $5.73 \times 10^{-4} \pm 1.33 \times 10^{-4}$ \\
Mar/07 & $2.35 \pm 0.21$ & $6.75 \pm 0.35$ & $5.75 \pm 0.35$ & $5.31 \times 10^{-4} \pm 7.41 \times 10^{5}$ \\
Apr/07 & $1.83 \pm 1.05$ & $6.46 \pm 1.16$ & $5.46 \pm 1.00$ & $4.64 \times 10^{-4} \pm 8.81 \times 10^{-5}$ \\
May/07 & $1.32 \pm 0.71$ & $5.5 \pm 0.92$ & $4.48 \pm 1.63$ & $7.24 \times 10^{-4} \pm 2.69 \times 10^{-4}$ \\
Jun/07 & $1.75 \pm 0.57$ & $6.21 \pm 0.82$ & $5.50 \pm 0.57$ & $5.90 \times 10^{-4} \pm 2.14 \times 10^{-4}$ \\
\hline
\end{tabular}


Table 2. Mean values of Pearson's correlation matrix between $\mathrm{pH}$, dissolved oxygen (D0), water temperature and rainfall, with prevalence and mean intensity of infection in the internal organs of Iguanodectes spilurus from northeastern Pará state, Brazil, between June 2006 and June 2007.

\begin{tabular}{|c|c|c|c|c|}
\hline Site of infection & $\mathrm{pH}$ & DO & Temperature & Rainfall \\
\hline & \multicolumn{4}{|c|}{ Prevalence } \\
\hline Stomach & -0.63 & 0.048 & -0.24 & 0.32 \\
\hline Anterior intestine & 0.16 & 0.10 & -0.47 & -0.08 \\
\hline Medium intestine & -0.59 & 0,13 & -0.36 & -0.03 \\
\hline Posterior intestine & -0.31 & 0.09 & -0.26 & -0.17 \\
\hline Liver & -0.59 & 0.13 & -0.36 & -0.15 \\
\hline \multirow[t]{2}{*}{ Caecum } & -0.68 & 0.04 & -0.25 & 0.62 \\
\hline & \multicolumn{4}{|c|}{ Mean intensity of infection } \\
\hline Stomach & -0.52 & 0.30 & -0.05 & 0.29 \\
\hline Anterior intestine & 0.01 & 0.10 & -0.46 & -0.17 \\
\hline Medium intestine & 0.02 & -0.06 & -0.14 & -0.16 \\
\hline Posterior intestine & -0.09 & 0.35 & -0.42 & 0.08 \\
\hline Liver & 0.07 & 0.29 & 0.21 & -0.42 \\
\hline Caecum & -0.64 & 0.02 & -0.26 & 0.41 \\
\hline
\end{tabular}

Table 3 - Mean values of Pearson's correlation matrix between mean weight $(W)$, total length (TL), standard length (SL) and condition factor $(\mathrm{Kn})$, with prevalence and mean intensity of infection in the internal organs of Iguanodectes spilurus from northeastern Pará state, Brazil, from June 2006 to June 2007.

\begin{tabular}{|c|c|c|c|c|c|c|c|c|}
\hline \multirow{2}{*}{$\begin{array}{l}\text { Site of } \\
\text { infection }\end{array}$} & \multicolumn{4}{|c|}{ Prevalence } & \multicolumn{4}{|c|}{ Mean intensity of infection } \\
\hline & W & $\mathrm{TL}$ & SL & $\mathrm{Kn}$ & W & TL & SL & $\mathrm{Kn}$ \\
\hline Stomach & 0.12 & 0.17 & -0.03 & -0.2974 & 0.01 & 0.15 & 0.07 & -0.3389 \\
\hline $\begin{array}{l}\text { Anterior } \\
\text { intestine }\end{array}$ & 0.25 & -0.28 & -0.36 & 0.1994 & -0.12 & -0.26 & -0.28 & 0.4237 \\
\hline $\begin{array}{l}\text { Medium } \\
\text { intestine }\end{array}$ & 0.21 & 0.15 & 0.14 & 0.0596 & -0.35 & -0.31 & -0.30 & 0.2468 \\
\hline $\begin{array}{l}\text { Posterior } \\
\text { intestine }\end{array}$ & 0.21 & 0.32 & 0.14 & -0.4105 & 0.12 & 0.17 & 0.15 & -0.2544 \\
\hline Liver & 0.02 & -0.07 & -0.09 & 0.2398 & -0.22 & -0.14 & 0.07 & 0.0617 \\
\hline Caecum & 0.34 & 0.44 & 0.26 & -0.5011 & 0.17 & 0.22 & 0.01 & -0.2492 \\
\hline
\end{tabular}

(Anisakidae) in the stomach, intestine and liver of fish. From a total of 176 specimens examined, 124 (70.4\%) were parasitized by larval nematodes. The highest prevalence per site of infection was found in the liver, with $57.4 \%$ prevalence and $4.7 \pm 2.1$ mean intensity of encysted larvae (Table 4). The highest total prevalence $(\mathrm{P}<0.01)$ was observed in the rainy period (Figure 2).
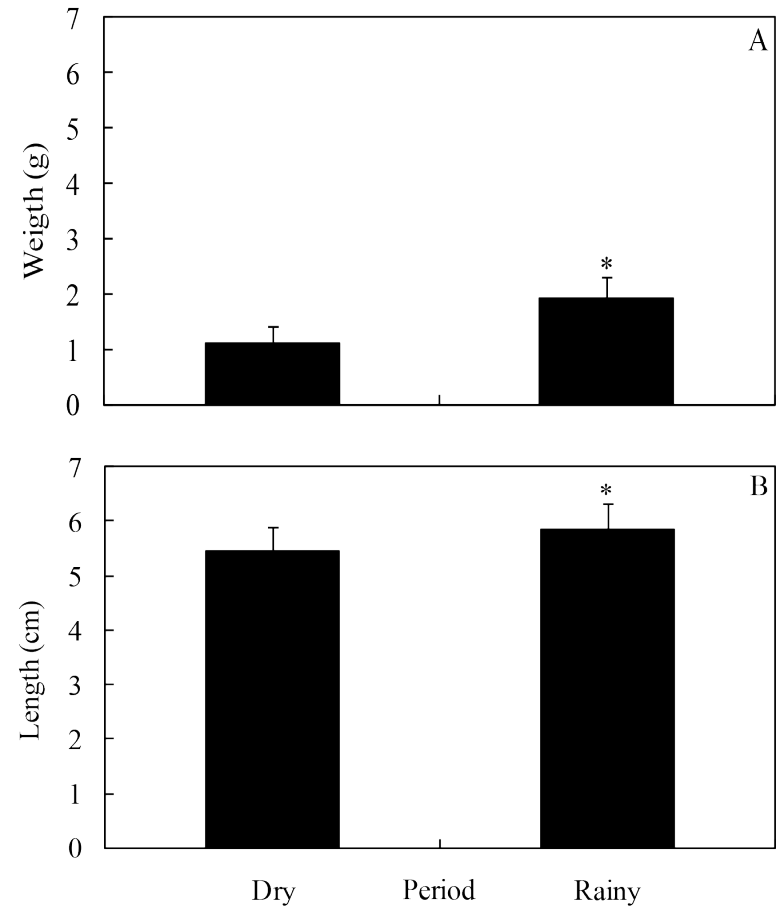

Figure 1 - Mean values and standard deviation of biometric data of Iguanodectes spilurus in the dry and rainy periods. A: weight. B: total length. * $p<0.01$

Table 4. Parasitological assessment in Iguanodectes spilurus from northeastern Pará state, Brazil, between June 2006 and June 2007. Data based on 176 examined fish.

\begin{tabular}{lllll}
\hline $\begin{array}{l}\text { Site of } \\
\text { infection }\end{array}$ & $\begin{array}{l}\text { Parasitized } \\
\text { fish }\end{array}$ & $\begin{array}{l}\text { Total number } \\
\text { of parasites }\end{array}$ & Prevalence (\%) & $\begin{array}{l}\text { Mean intensity } \\
\text { of infection }\end{array}$ \\
\hline $\begin{array}{l}\text { Stomach } \\
\text { Anterior } \\
\text { intestine }\end{array}$ & 31 & 72 & 17.61 & $2.32 \pm 1.47$ \\
$\begin{array}{l}\text { Medium } \\
\text { intestine }\end{array}$ & 30 & 62 & 17.04 & $2.06 \pm 0.89$ \\
$\begin{array}{l}\text { Posterior } \\
\text { intestine }\end{array}$ & 22 & 40 & 12.50 & $1.81 \pm 1.03$ \\
$\begin{array}{l}\text { Liver } \\
\text { Caecum }\end{array}$ & 101 & 475 & 57.38 & $4.70 \pm 2.13$ \\
\hline & 19 & 42 & 10.79 & $2.21 \pm 1.22$ \\
\hline
\end{tabular}

DISCUSSION

Low water quality, such as water with low dissolved oxygen contents, decreases fish resistance and may provoke parasitic and bacterial infections (Martins, 2004). Consequently, the low variation in aquatic parameters did not influence the parasitic infection in I. spilurus. This fish can be found living in waters of varied dissolved oxygen (from 4.93 to $7.12 \mathrm{mg}$ $\left.\mathrm{L}^{-1}\right)$ concentrations, as reported by Anjos (2005) in the Central Amazon. 

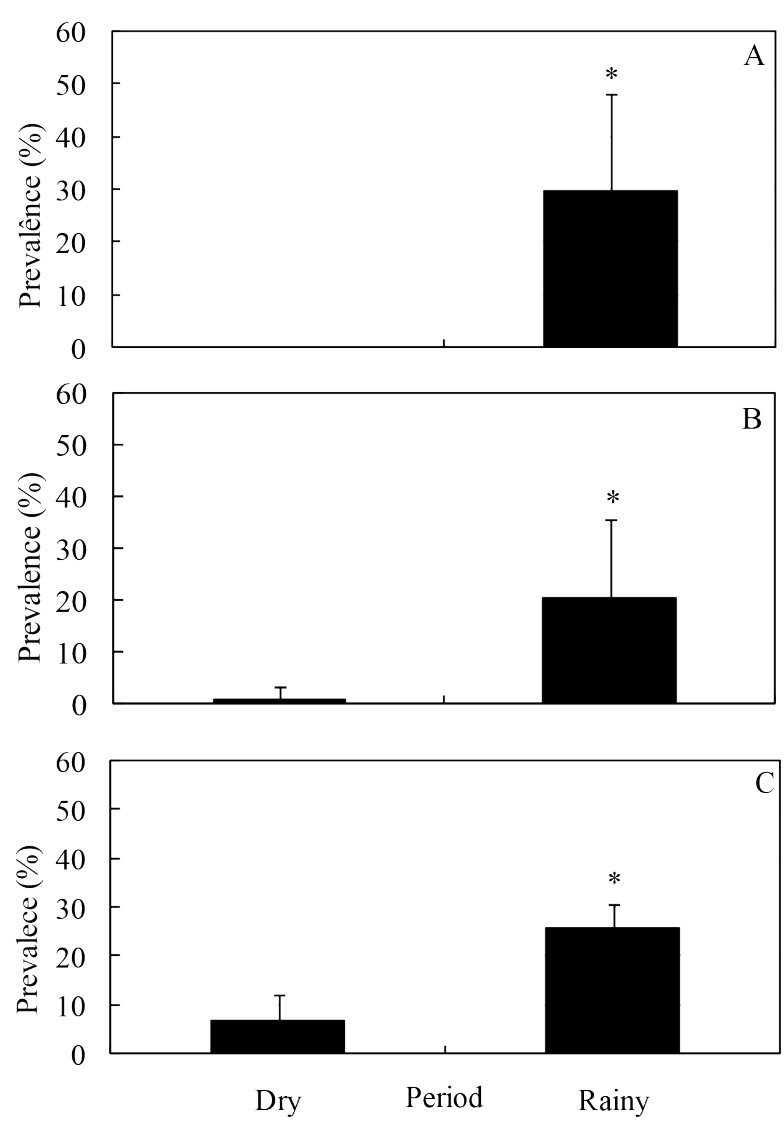

Figure 2 - Mean values and standard deviation of prevalence (\%) of nematode larvae in the caecum (A), stomach (B) and posterior intestine (C) in Iguanodectes spilurus in the dry and rainy periods. ${ }^{*} p<0.01$

Decreased levels of $\mathrm{pH}$ were found in February, April and May 2007 (rainy season), which can be associated to organic matter decomposition. In July 2006, high values of $\mathrm{pH}$ (9.14) and dissolved oxygen (6.8 $\left.\mathrm{mg} \mathrm{L}^{-1}\right)$ were observed, they were possibly related to an adverse condition. In fact, this condition could be associated to a transition period between the rainy and dry seasons. Water quality, such as $\mathrm{pH}$ and oxygen contents and temperature, did not influence the parasitological data for I. spilurus.

In this study, Iguanodectes spilurus harbored nematodes in larval stage such as found by Fischer et al. (2004) in the Amazonian fish tambaqui, Colossoma macropomum. Encysted nematodes represent a strategy against the defense of hosts, contributing to parasite survival and dissemination. The importance of nematode larvae as biological indicators and the distinction of host populations in aquatic ecosystems were evaluated by Mackenzie (1983), for example, anisakid worms. Similarly, Rodrigues et al. (2002) observed 15.3\% prevalence of nematodes in the liver of dourado, Salminus maxillosus, which caused histological alterations such as inflammatory reaction of the host.

Increased weight and length of fish during the rainy season may be related to increased food ingestion, facilitated by the stream overflow, with large amounts of organic matter (Abelha et al. 2001). According to Claro Jr. et al. (2004), the diet composition of Amazonian fish varies as a consequence of the overflow of rivers. During the flood period in the Amazon, a diversification of habitats such as nutrient intake and ichthyofauna alterations was observed in Triportheus angulatus by Yamamoto et al. (2004). The highest prevalence rate and mean intensity of infection in the stomach, posterior intestine and caecum were observed in the rainy season. According to the findings by Tavares and Luque (2001), in parasitized common snook Centropomus undecimalis, the increased number of parasites was closely related to the feeding habitat and not to the parasitic accumulation process. Isaac $e t$ al. (2004) commented that the endoparasitic fauna of knife fish Gymnotus spp. was strongly associated to feeding, mainly composed by crustaceans and insects. Alike the present study, Martins et al. (2003a) found the highest mean intensity of infection by nematode Ichthyouris voltagrandensis in characid fish from a reservoir in the State of Minas Gerais in rainy season.

In traira, Hoplias malabaricus, caught in the Cuiaba River, Contracaecum sp. and Eustrongylides sp. larvae occurred mostly in the muscles and viscera at prevalence rates of 73 and 33\%, respectively (Barros et al. 2007). The authors argued that infection was favored by the ingestion of intermediate hosts as a result of the flooding on that region. In contrast, no difference was reported either in parasitism or in seasonality of Procamallanus (Spirocamallanus) pintoi, from peppered corydoras, Corydoras paleatus, in the State of Parana, Southern Brazil (Ito et al. 2005). In the present study, although larger fish were collected in the rainy season, no significant correlation was observed between the weight and length of hosts and parasitism, similarly to that found by Tavares et al. (2001).

The occurrence of Procamallanus $\mathrm{L}_{3}$ larvae in I. spilurus suggests that the feeding habitat of this fish may be composed of copepods, as verified by Martins et al. (2007) in experimental infection with camallanid larvae in Notodiaptomus sp. (Crustacea: Calanoida). Parasitic infection in Amazonian fish is related to a variety of food items along their ontogenetic development in rivers, as suggested by Goulding (1980). These changes were observed at the beginning of fish development, when fish feed temporarily on zooplankton (Cowan et al. 1997).

High prevalence of Contracaecum larvae in piscivorous fish H. malabaricus, reported by Martins et al. (2003b), suggests I. spilurus as intermediate host. The presence of capillariid 
larvae in the liver suggests that I. spilurus is an intermediate host, once adult nematodes are normally found in piscivorous birds (Yanong 2002).

No correlation between condition factor and parasitism was observed, which demonstrates that, in this case, the nematode larvae did not harm fish health, as also reported by Dias et al. (2004) and Moreira et al. (2005), who observed no influence of parasitism on the condition factor of Neotropical fish. In contrast, increased condition factor was reported to parasitized curimbata, Prochilodus lineatus, from the upper Parana River floodplain.

\section{CONCLUSION}

The liver was the most sensitive organ to nematode larvae. In the rainy season, increased parasitism was found in the stomach, posterior intestine and caecum of I. spirulus. The parasitological assessment was not influenced by abiotic factors ( $\mathrm{pH}$, oxygen and temperature), but this study reported for the first time the presence of nematode larvae in I. spirulus, a poorly studied Amazonian freshwater fish species. Further studies should be carried out not only with Amazonian freshwater ornamental fishes, but also with the first intermediate hosts.

\section{ACKNOWLEDGEMENTS}

The authors are grateful to the National Council of Scientific and Technological Development - CNPq for the financial support to M.L. Martins and to Coordination for the Improvement of Higher Education Personnel. CAPES for the $\mathrm{PhD}$ scholarship to Fabrício Ramos Menezes.

\section{REFERENCES}

Abelha, M.C.F.; Agostinho, A.A.; Goulart, E. 2001. Trophic plasticity in freshwater fishes. Acta Scientiarum Biological Sciences, 23: 425-434.

Anjos, M.B. 2005. Estrutura de comunidades de peixes de igarapés de terra firme na Amazônia Central: composição, distribuição e características tróficas. Dissertação de Mestrado, Universidade Federal do Amazonas, Manaus. 81p. URL:http://www. igarapes.bio.br/index.php?option=com_docman\&task=cat_ view $\&$ gid $=18 \&$ Itemid $=48$.

Barros, L.A.; Filho, J.M.; Oliveira, R.L. 2007. Larvas de nematóides de importância zoonótica encontradas em traíras (Hoplias malabaricus Bloch, 1794) no município de Santo Antonio do Leverger, MT. Arquivo Brasileiro Medicina Veterinária e Zootecnia, 59: 533-535.

Bush, A.O.; Lafferty, K.D.; Lotz, J.M.; Shostak, A.W. 1997. Parasitology meets ecology on its own terms: Margolis, L; Esch, G.L. Homes, J.C.; Kuris, A.M.; Schad, G.A. Revised. Journal of Parasitology, 83: 575-583.

Claro JR, L.; Ferreira, E.; Araújo-Lima, J.J. 2004. O efeito da floresta alagada na alimentação de três espécies de peixes onívoros em lagos de várzea da Amazônia central, Brasil. Acta amazonica, 34: 133-137.

Cowan, J.H.; Rose, K.A.; Houde, E.D. 1997. Size-based foraging success and vulnerability to predation: selection of survivors in individual-based models of larval fish populations. p. 357-389. In: Chambers, C.; Trippel, E.A. (Eds.). Early life historyand recruitment in fish populations. London: Chapman \& Hall.

Dias, P.G.; Furuya, W.M.; Pavanelli, G.C.; Machado, M.H.; Takemoto, R.M. 2004. Carga parasitária de Rondonia rondoni Travassos, 1920 (Nematoda, Atractidae) e fator de condição do armado, Pterodoras granulosus Valenciennes, 1883 (Pisces, Doradidae). Acta Scientiarum Biological Sciences, 26: 151-156.

Eiras, J.C.; Pavanelli, G.C.; Souza, J.A.; Takemoto, R.M.; RanzaniPaiva, M.J.T. 1998. Ocorrência de agentes com potencial patogênico em peixes de dois pesque-pagues e uma piscicultura do norte do Estado do Paraná. Anais do Aquicultura Brasil, 2: 697-701.

Eiras, J.C.; Takemoto, R.M.; Pavanelli, G.C. 2006. Métodos de estudo e técnicas laboratoriais em parasitologia de peixes. Maringá: UEM. 171 p.

Fischer, C.; Malta, J.C.O.; Varella, A.M.B. 2004. A fauna de parasitos do Tambaqui, Colossoma macropomum (Cuvier, 1818) (Characiformes: Characidae) do médio rio Solimôes, Estado do Amazonas (AM) e do baixo rio Amazonas, Estado do Pará (PA), e seu potencial como indicadores biológicos. Acta Amazonica, 33: 651-662.

Goulding, M. 1980. The fishes and the forest: explorations in amazon natural history. Berkeley: University of California Press. 269 p.

Günther, A. 1864. Catalogue of the fishes in the British Museum. Vol. 5. Catalogue of the Physostomi, containing the families Siluridae, Characinidae, Haplochitonidae, Sternoptychidae, Scopelidae, Stomiatidae in the colletion of the British Museum. Trustees, London. 455p.

Isaac, A.G.; Guidelli, M.J.; Pavanelli, G.C.; Galvão, P. 2004. Composição e estrutura das infracomunidades endoparasitárias de Gymnotus spp. (Pisces: Gymnotidae) do rio Baía, Mato Grosso do Sul, Brasil. Acta Scientiarum Biological Sciences, 26: 453-462.

Ito, K.F.; Moreira, S.T.; Takemoto, R.M.; Pavanelli, G.C. 2005. Ecological aspects of the Procamallanus (Spirocamallanus) pintoi parasite of Corydoras paleatus (JENYNS,1842) (Siluriformes: Callichthyidae) in reservoirs of the State of Paraná, Brazil. Acta Scientiarum Biological Sciences, 27: 239-242.

Le Cren, E.D. 1951. The length-weight relationship and seasonal cycle in gonadal weight and condition in the perch (Perca fluviatilis). Journal of Animal Ecology, 20: 201-219.

Mackenzie, K. 1983. Parasites as biological tags in fish population study. Advances in Applied Biology, 7: 251-331.

Martins, M.L. 2004. Manejo sanitário na Piscicultura, p. 323-332. In: Ranzani-Paiva, M.J.T.; Takemoto, R.M.; Lizama, M.A.P. (Eds.). Sanidade de organismos aquáticos. São Paulo: Varela.

Martins M.L.; Fenerick J.JR.; Nomura D.T.; Braga, F.M.S. 2003a. Prevalence, intensity and seasonality of Ichthyouris voltagrandensis (Nematoda: Pharyngodonidae) in Myleus tiete (Osteichthyes: 
Characidae) from Volta Grande Reservoir, Minas Gerais State, Brazil. Boletim do Instituto de Pesca, 29: 39-46.

Martins, M.L.; Santos, R.S.; Takahashi, H.K.; Marengoni, N.G.; Fujimoto, R.Y. 2003b. Infection and susceptibility of three fish species from the Paraná River, Presidente Epitácio, State of São Paulo, Brazil, to Contracaecum sp. larvae (Nematoda: Anisakidae). Acta Scientiarum Animal Sciences, 25: 73-78.

Martins, M.L.; Ghiraldelli, L.; Garcia, F.; Onaka, E.M.; Fujimoto, R.Y. 2007. Experimental infection in Notodiaptomus sp. (Crustacea: Calanoida) with larvae of Camallanus sp. (Nematoda: Camallanidae). Arquivo Brasileiro de Medicina Veterinária e Zootecnia, 59: 382-386.

Moraes, F.R.; Martins, M.L. 2004. Predisposing conditions and principal diseases of intensive fish farming teleosts. p. 343-383. In: Cyrino, J.E.P.; Urbinatti, E.C.; Fracalossi, D.M.; Castagnolli, N. (Eds.). Especial topics in intensive freshwater fish culture in the Tropics. São Paulo: Tec Art.

Moreira, S.T.; Ito, K.F.; Takemoto, R.M.; Pavanelli, G.C. 2005. Ecological aspects of the parasites of Iheringichthys labrosus (Lütken, 1874) (Siluriformes: Pimelodidae) in reservois of Paraná basin and upper Paraná floodplain, Brazil. Acta Scientiarum Biological Sciences, 27: 317-322.

Rodrigues, E.L.; Ranzani-Paiva, M.J.T.; Santos, A.A. 2002. Alteraçóes histopatológicas em fígado de Dourado Salminus Maxillosus Valenciennes, 1840 (Osteichtyes, Characidae) causadas por Neocucullanus Noecuculanus Travassos, Artigas e Pereira 1828 (Nematoda). Acta Scientiarum Biological Sciences, 24: 455-459.

Schaeffer-Novelli, Y.; Cintron, G. 1986. Guia para estudo de Áreas de Manguezal. São Paulo: Caribbean Ecological Research. 150 p.

Tavares, L.E.R; Luque, J.L.; Neto, S.L.B. 2001. Ecologia da comunidade de metazoários parasitos do olho-de-cão Priacanthus arenatus (Cuvier, 1829) (Osteichthyes, Priacanthidae) do litoral do estado do Rio de Janeiro, Brasil. Revista Brasileira de Zoociências, 1: 45-59.

Tavares, L.E.R.; Luque, J.L. 2001. Aspectos quantitativos das infrapopulaçóes de Caligus praetextusBere, 1936 (Copepoda: Caligidae) parasito do robalo, Centropomus undecimalis (Osteichthyes: Centropomidae) no litoral do Estado do Rio de Janeiro. Revista Brasileira de Zoociências, 3: 253-258

Thatcher, V.E. 2006. Amazon fish parasites. 2a ed. Moscow: Pensoft Publishers. 508 pp.

Travassos, L.; Artigas, P.; Pereira, C. 1928. Fauna helminthologica dos peixes de água doce do Brasil. Archivos do Instituto Biológico, 1: 5-68.

Vari, R.P. 1977. Notes on the characoid subfamily Iguanodectinae, with a description of a new species. American Museum of Natural History, 2612: 1-6.

Yamamoto, K.C; Soares, M.G.M.; Freitas, C.E.C. 2004. Alimentação de Triportheus angulatus (Spix \& Agassiz,1829) no lago Camaleão, Manaus, AM, Brasil. Acta Amazonica, 4: 653-659.

Yanong, R. P. E. 2002. Nematode (roundworm) infections in fish. Department of Fisheries and Aquatic Sciences, Florida Cooperative Extension Service, University of Florida. Institute of Food and Agricultural Sciences, 91: 1-9.

Aceito em: 22/08/2012

Recebido em: 15/01/2013 